\title{
Amphibians and Reptiles of the Nature Reserve of Pergusa Lake (Enna, Italy), emphasizing Sicilian endemisms
}

\author{
Rosa Termine' \& Giuseppe Fabrizio Turrisi² \\ ${ }^{1}$ Laboratory of Sanitary Environmental Engineering, Section of Biology, "Kore” University of Enna, Cittadella Universitaria, 94100 \\ Enna, Italy; e-mail: rosa.termine@unikore.it \\ ${ }^{2}$ Via Cristoforo Colombo 8, 95030, Pedara, Catania, Italy; e-mail: giuseppefabrizioturrisi@gmail.com
}

\begin{abstract}
A brief survey on the herpetofauna of the Nature Reserve of Pergusa Lake (Enna, Italy) is provided, highlighting the Sicilian endemic taxa. For this protected area, it is confirmed the presence of 12 species, 4 Amphibians and 8 Reptiles, with two strictly Sicilian endemic taxa: Bufotes siculus (Stöck, Sicilia, Belfiore, Buckley, Lo Brutto, Lo Valvo et Arculeo, 2008), and Emys trinacris Fritz, Fattizzo, Guicking, Tripepi, Pennisi, Lenk, Joger et Wink, 2005, and the siculo-maltese Discoglossus pictus pictus Otth, 1837. Data on the habitat preference and other aspects of ecology and conservation of the recognized species are provided. The research especially confirms the ecological and conservation importance of the protected area for the endemic Bufotes siculus and Emys trinacris due to their significant populations.
\end{abstract}

KEY WORDS Amphibians, Reptiles, Pergusa Lake, Nature Reserve, faunal list, Ecology, Conservation.

Received 21.05.2020; accepted 22.06.2020; published online 30.06.2020

\section{INTRODUCTION}

The study of the Sicilian herpetofauna has a long tradition (Bruno, 1970), although there are only scattered and incomplete data published till the mid-90s. However, especially in the last two decades, several comprehensive studies (e.g., Turrisi \& Vaccaro, 1998; Sindaco et al., 2006; Turrisi et al., 2008; Lo Valvo et al., 2017) improved the knowledge of the Sicilian herpetofauna mainly with regard to Regional distribution, albeit the ecological and conservation aspects still remain poorly investigated, with very few monitoring research (Turrisi et al., 2008; Lo Valvo et al., 2017). The herpetofauna of central Sicily is unsatisfactorily known compared with other recently explored $\mathrm{Si}$ cilian territories (Turrisi, 1996; Turrisi \& Vaccaro, 1998; Turrisi \& Vaccaro, 2004a, 2004b; Sindaco et al., 2006; Turrisi et al., 2008; Restivo et al., 2010a, 2010b; Vaccaro \& Turrisi, 2010; Lo Valvo et al., 2017) and still await further monitoring research.

The present paper deals with a brief summary of the herpetofauna of Nature Reserve of Pergusa Lake (Enna, Italy) as an update after the contributions by Turrisi (2004, unpubl.), Termine et al. (2008), and Termine \& Turrisi (2016), emphasizing Sicilian endemisms, all of them having close ecological relationships with the water bodies and the riparian area. We also highlight and discuss some conservation aspects as a framework for future monitoring programmes.

We are pleased to dedicate the present paper in honour of an authoritative Naturalist, our friend Prof. Bruno Massa (Palermo), for his great longtime efforts to the knowledge and protection of the biodiversity of Sicily. 


\section{MATERIAL AND METHODS}

\section{Study area}

The Nature Reserve "Lago di Pergusa" (Figs. 12) is located in central Sicily (667 m a.s.1.) and is managed by "Libero Consorzio Comunale di Enna". This protected area covers 402,5 ha and rep- resents a rare example of natural Sicilian endorheic lake (Grasso et al., 2003); its average water salinity has been 7.3 ppt in 2014 (Termine, 2015, unpubl.). It is also included in the network Natura 2000 as core breeding and resting site for rare and threatened species, and some rare natural habitat types which are protected in their own right (Termine et al., 2008).

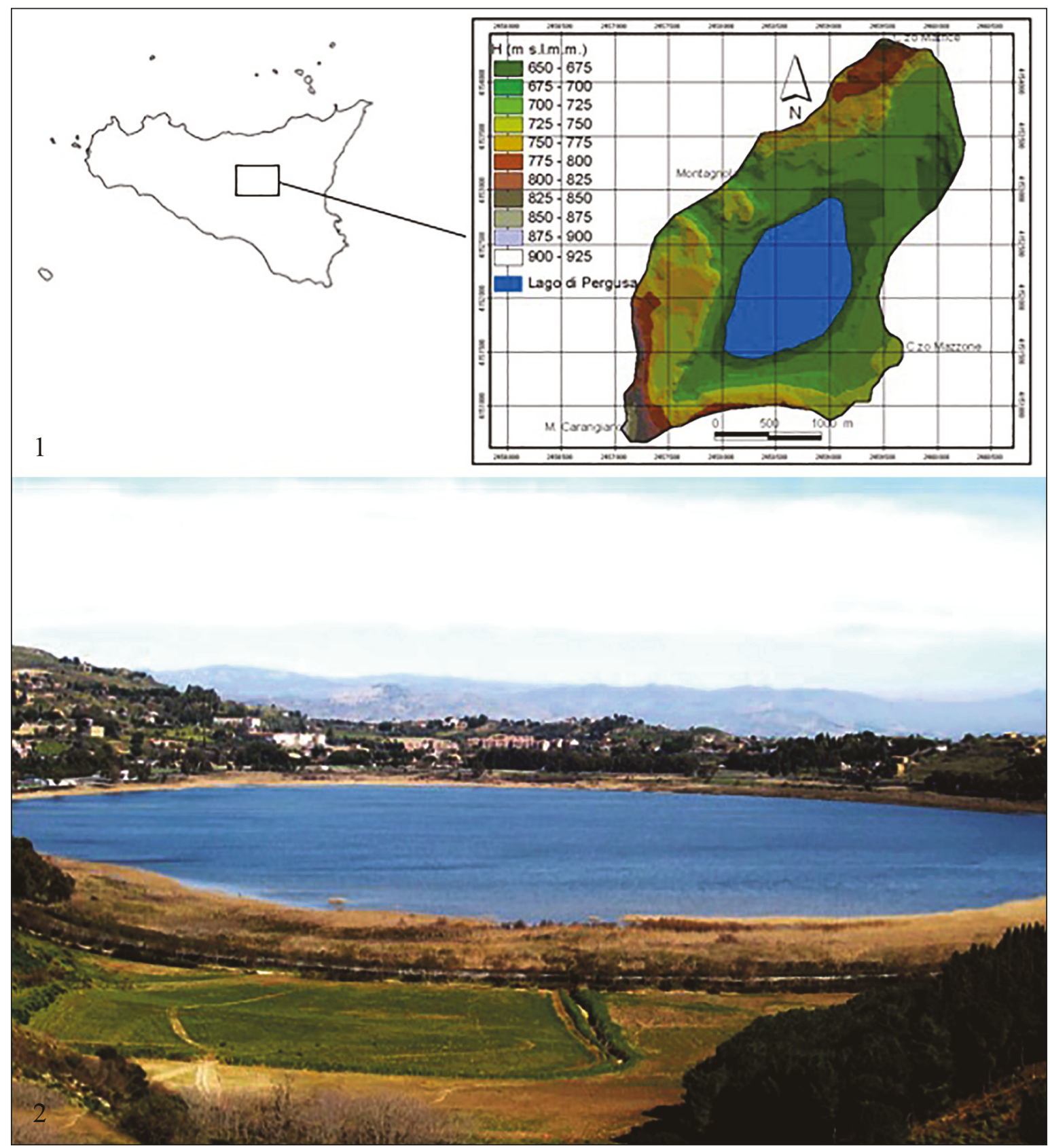

Figure 1. Study area (map elaborated by Elena Amore, 2005). Figure 2. View of Pergusa Lake (Enna). 


\section{Sources and data treatment}

Based on a monitoring plan of more than twenty years (1996-2019), the faunistic presence of both amphibians and reptiles in the study area is updated, emphasizing three herpetological endemisms. Their presence has been evaluated in detail with regard to phenology, habitat preference, estimate population size and breeding sites. The investigations have been carried out through direct observations of specimens, eggs, larvae, clutches, and song signals. The data were stored in a database for further elaboration, and have been added to the Sicilian Herpetological Database (Turrisi \& Vaccaro, ongoing) to update the Sicilian Herpetological Atlas (Turrisi et al., 2008). The systematic account follows the recent checklist of the European herpetofauna (Speybroeck et al. (2020), although we still consider Bufotes siculus (Stöck, Sicilia, Belfiore, Buckley, Lo Brutto, Lo Valvo, Arculeo, 2008) at a full species rank instead of subspecies of $B$. boulengeri, as documented and supported by Colliard et al. (2010).

\section{RESULTS}

\section{Faunistic account}

Our research shows that Pergusa Lake is a hotspot of herpetological diversity in the context of central Sicily, including 12 species, 4 Amphibians and 8 Reptiles (Table 1), with two strictly interesting Sicilian endemic taxa: Bufotes siculus, and Emys trinacris (Turrisi, 2004, unpubl.; Termine, 2006a; Termine et al., 2008). We also still consider Discoglossus pictus pictus as valid subspecies, a putative siculo-maltese endemism (Turrisi et al., 2008), since it has been confirmed as a distinct genetic lineage, although weakly differentiated from the other subspecies, D. pictus auritus Héron-Royer, 1888 (Zangari et al., 2006), distributed in Tunisia and Algeria (introduced in Spain and southern France), and thus having a significant biogeographic and conservation interest (Turrisi \& Vaccaro, 1998; Turrisi, 2008a). Hyla intermedia Boulenger, 1882 is recorded for "Pergusa" by Bruno (1970), but it has not been confirmed, and it is presently excluded from the checklist.

\section{The Sicilian endemisms}

Three Sicilian endemic or sub-endemic taxa are recorded in the study area.

The Painted Frog, Discoglossus pictus (Fig. 3) has a West Mediterranean distribution pattern being present in North Africa (Algeria and Tunisia), Italy (Sicily), and Maltese Islands (Malta and Gozo) (Stöck et al., 2015). It is widespread in Sicily with some deficient data for central and southern parts (Turrisi, 2008a; Lillo et al., 2013; Lo Valvo et al., 2017). Ecological preferences, shows that it is frequent along the riparian area of the lake, and in some small ponds around the lake (Turrisi, 2004 unpubl.; Termine et al., 2008). The main breeding sites occur in a narrow peripheral side of the lake, where the body water is not deep and partly covered by vegetation. We highlighted almost regular breeding and migratory events for Discoglossus pictus pictus, which during March-October shows a number of specimens (mostly neo-metamorphosed) around the lakeside.

The Sicilian Green Toad, Bufotes siculus (Fig. 4), has a north-African origin (having as sister clade B. boulengeri Lataste, 1879), and occupies the western and southern parts of Sicily (with some de-

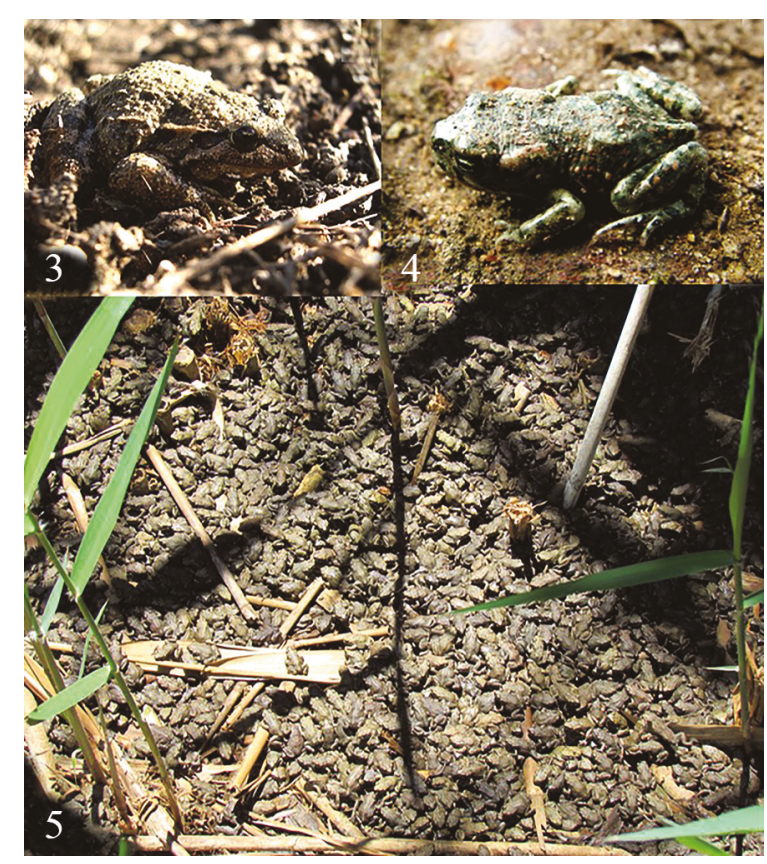

Figure 3. Discoglossus pictus pictus, adult. Figure 4. Bufotes siculus, subadult. Figure 5. Massive aggregation of Bufotes siculus. 
ficient data in the remaining territories), as well as two small islands off the north-western coasts (Ustica and Favignana) (Stöck et al., 2008; Sicilia, 2008; Colliard et al., 2010; Lo Valvo et al., 2017). It is very common and abundant in the study area. Most of the breeding sites are included in a narrow part of outer lake, where the body water is not deep and partly covered by vegetation. We highlighted almost regular explosive breeding and migratory events (Fig. 5) during May-August, for 1 to 6 weeks, with very high population density around the lakeside (estimated 50-400 specimens $/ \mathrm{m}^{2}$ ), including mostly neo-metamorphosed mixed-up with a small number of specimens of Discoglossus pictus pictus. According to our data, in the late spring of 1996 a huge explosive breeding and migratory event was documented, whereas in the subsequent years, up to 2002, no relevant observations have been done; from 2003 to-date, several explosive presences of this taxon have been regularly observed.

The Sicilian Pond Turtle, Emys trinacris (Fig. 6), has a widespread but fragmentary distribution in Sicily mainland, especially in the north and central parts (Turrisi, 2008b; Di Cerbo, 2010). Pergusa Lake is currently one of the most important breeding site for E. trinacris in central Sicily, with regular observations of specimens during basking, foraging, migration and nesting. The first detection was on 29.IV.2005 of an adult male, after the increasing of the lake water level, started on 2003. Previously, from the late ' 80 s to 2002 , Emys trinacris abandoned the main site to populate alternative neighbouring wet sites, e.g., one pond located on a south-west hill, since Pergusa Lake became almost drained, with very high degree of salinity (values more than 70 ppt registered in July 2002 according to Termine, 2006b). Several observations over the subsequent six-years period corroborate the presence of a stable reproductive population, as summarized and detailed in the following. The first oviposition was directly observed on 02 .VIII.2014 in the east side of the lake $\left(37^{\circ} 30^{\prime} 57,35^{\prime \prime} \mathrm{N}\right.$; $\left.14^{\circ} 18^{\prime} 46,25^{\prime \prime} \mathrm{E}\right)$, in an open and sloping area, at about $5 \mathrm{~m}$ from the lakeshore; in the same day, close to this nest, a holed nest was observed, destroyed by an unidentified predator, containing mixed-up broken eggs and one entire egg (length/width: 29/18 mm) (Figs 7, 8). An adult male (carapace length/width: 155/115 mm) has been observed on
16.VI.2015 while walking over car tracks (37 $\left.31^{\prime} 18,96^{\prime \prime} \mathrm{N} ; 1^{\circ} 18^{\prime} 33,10^{\prime \prime} \mathrm{E}\right)$, at about $60 \mathrm{me}-$ ters from the lake border. Another specimen has been observed during oviposition on 13.VII.2016 in the same river $\left(37^{\circ} 30^{\prime} 57,71\right.$ ' $\mathrm{N}$; $14^{\circ} 18^{\prime} 46,29$ ' $\left.\mathrm{E}\right)$, about six meters far from the water and 11 meters far from the previous oviposition site. In the same day, at about 30 meters far from the latter oviposition site $\left(37^{\circ} 30^{\prime} 58,67^{\prime \prime} \mathrm{N} ; 4^{\circ} 18^{\prime} 46,36^{\prime \prime} \mathrm{E}\right)$, a holed nest has been observed, closely bearing fecal rest probably of the Red Fox, Vulpes vulpes Linnaeus, 1758. Two just hatched juveniles (Fig. 9) have been observed on 11.IV.2017 (carapace length/width: 27/17 mm; plastron length/width: $24 / 17 \mathrm{~mm}$ ), in the north side of the lake $\left(37^{\circ} 31^{\prime} 12,72^{\prime}\right.$ 'N $\left.14^{\circ} 18^{\prime} 24,75^{\prime} \mathrm{E}\right)$ while reaching the water; in the same place a male has previously been observed on 14.III.2017 (carapace length/width: 152/112 mm; plastron length/width: 130/72 mm). Two different predations have been documented, respectively on 28.VII.2017 (37०30'55,51'"N; 14 $\left.{ }^{\circ} 18^{\prime} 45,94^{\prime \prime} \mathrm{E}\right)$ and 16.VIII.2017 (3730'56,02”'N; $14^{\circ} 18^{\prime} 46,05^{\prime}$ 'E) along the river. Until recently, an adult male (carapace length/width: 142/103 mm) has been observed on 12.VI.2018 along the west river (37 $30^{\prime} 49,36^{\prime \prime} \mathrm{N}$; $\left.14^{\circ} 18^{\prime} 0,13^{\prime \prime} \mathrm{E}\right)$. Another holed nest has been observed on 10.VII.2018 along the east river $\left(37^{\circ} 31^{\prime} 0,00^{\prime \prime} \mathrm{N} ; 1^{\circ} 18^{\prime} 46,28^{\prime}\right.$ 'E). Finally, a predation case has been documented on 06.VI.2019 along the east river $\left(27^{\circ} 30^{\prime} 54,84^{\prime}{ }^{\prime} \mathrm{N} ; 1^{\circ} 18^{\prime} 46,02^{\prime \prime} \mathrm{E}\right)$, close to the previous documented cases.

In Pergusa Lake, Emys trinacris basking takes place along the lakeside or on floating substrates built by Porphyrio porphyrio (Linnaeus, 1758) with Phragmites australis (Cav.) Trin. ex Steud. stems (Termine, 2014); a maximum of three specimens has been observed in the same place.

\section{CONCLUSIONS}

The data accumulated until now put in evidence that the three endemic Sicilian herpetological taxa, two amphibians and one reptile have significant populations in Pergusa Lake, with moderately to high population-density and widespread local distribution. The conservation status of all the three taxa can be currently considered satisfactory enough, although exposed to some significant anthropogenic disturbance. For 

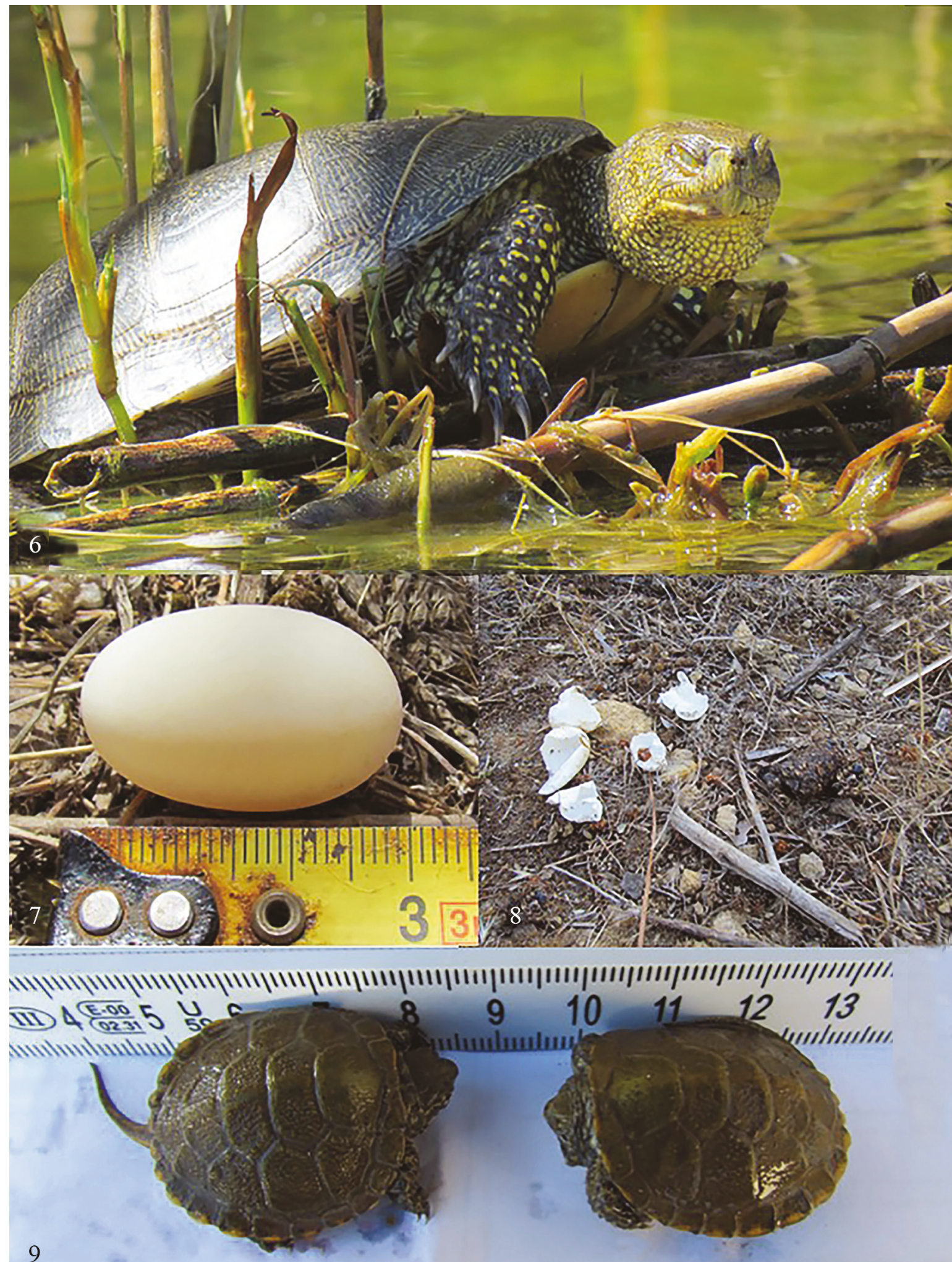

Figure 6. Emys trinacris, adult. Figure 7. Emys trinacris egg. Figure 8. Emys trinacris, holed nest after predation (on the right, fecal rest possibly of Vulpes vulpes). Figure 9. Emys trinacris, hatchlings. 


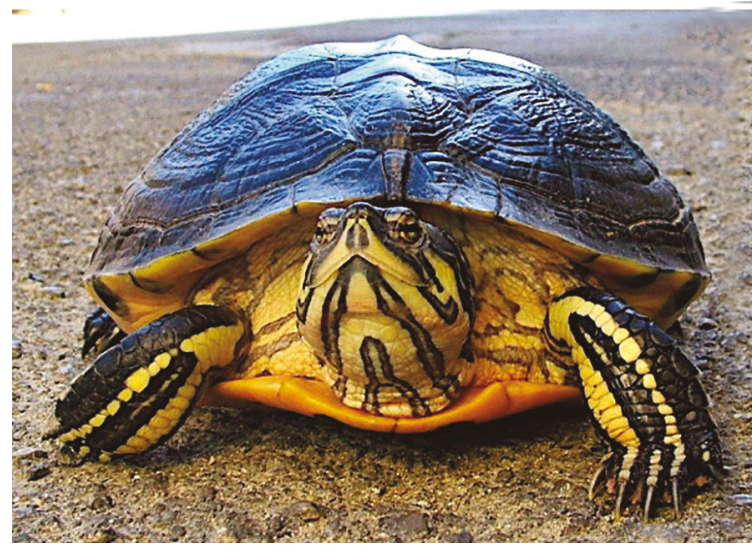

Figure 10. Trachemys scripta, adult.

instance, the presence of the autodrome around the Lake, although its use is under some restrictions, as well as of a peripheral public road close to the autodrome, represent remarkable and serious ecological problems, affecting the conservation status especially of amphibians, due to their explosive migratory and breeding behaviour, with frequent, significant road-killing events. This suggests that effective under-road passages should be built in order to mitigate this problem (Turrisi, 2004 unpubl.; Termine et al., 2008).

In Sicily, the presence of the allochthon Trachemys scripta (Schoepff, 1792) (Fig. 10) has been detected several times (Bella \& Turrisi, 2005; Lillo, 2008) with two subspecies T. scripta elegans (Wied, 1839) and T. scripta troosti (Holbrook, 1836) being represented in the site. The first detection in the area was in San Giovannello, in an artificial body water on 24.VII.2004 (G.F. Turrisi, pers. obs.). Further detection was on 10.III.2006, with observation of an adult specimen in the north side of the lake, on Razza Pier. Subsequently, additional records confirmed the presence of the two-above-mentioned subspecies, with several specimens observed along the autodrome, in the east and south-east sides of the lake; some specimens were collected and delivered to the local Forestry Authority and subsequently to the Wildlife Recovery Center of Ronza, Piazza Armerina, Enna. Very recently, an egg-bearing female was induced to lay artificially by injection of oxytocin, thus confirming that this alien species is able to develop eggs and thus, possibly to reproduce in the site (Liuzzo et al., 2020). The presence of the T. scripta suggests the need of care- ful monitoring programme for possible ecological impacts on indigenous communities, and especially for possible competition with the endemic Emys trinacris, currently not well understood.

The presence and the relative extension of wetland and water bodies of Sicily is of primary importance especially for amphibians and aquatic avifauna, and their role have been recently highlighted by Sarà et al. (2011). The data shown demonstrates how the Nature Reserve of Pergusa Lake is important for the conservation not only of birds (Termine et al., 2008) and biodiversity as a whole, but also with regards to herpetological taxa living in wet ecosystems, and how minimal anthropogenic interventions can perturb natural characters. The physiographic features, and the host of a high biodiversity (Termine et al., 2008), make this ecosystem unique and precious in the Sicilian context and allow us to understand the enormous potential that it could have in the Mediterranean framework for the protection of biodiversity.

Our results emphasize the need for considering functional aspects of the ecological traits of the herpetological fauna, to improve management actions for conservation strategies, especially of the Sicilian endemic taxa, in order to preserve both diversity and ecosystem functioning.

\section{ACKNOWLEDGEMENTS}

We would like to thank the "Libero Consorzio Comunale di Enna" (Italy) for supporting our research.

\section{REFERENCES}

Bella S. \& Turrisi G.F., 2005. Status e conservazione dei Testudinati in Sicilia. WWF Sicilia, 50 pp.

Bruno S., 1970. Anfibi e Rettili di Sicilia (Studi sulla Fauna Erpetologica Italiana. XI), Atti dell'Accademia Gioenia di Scienze Naturali, Catania, 2: 185-326.

Colliard C., Sicilia A., Turrisi G.F., Arculeo M., Perrin N., Stöck M., 2010. Strong reproductive barriers in a narrow hybrid zone of West-Mediterranean green toads (Bufo viridis subgroup) with Plio-Pleistocene divergence. BMC Evolutionary Biology, 10: 232-247.

Di Cerbo A., 2010. Emys trinacris. In: Corti C., Capula M., Luiselli L., Razzetti E., Sindaco R. (Eds.), Fauna d'Italia, Reptilia. Calderini, Bologna, pp. 163-168.

Fritz U., Fattizzo T., Guicking D., Tripepi S., Pennisi M.G., Lenk P., Joger U., Wink M., 2005. A new cryp- 
tic species of pond turtle from southern Italy, the hottest spot in the range of the genus Emys. Zoologica Scripta, 34: 351-371.

Grasso M., Amore C., Maniscalco R., Geremia F., Ingrasciotta V., Ioppolo S., 2003. Dati preliminari sulle ricerche stratigrafiche e sedimentologiche eseguite nel Lago di Pergusa (Enna). Bollettino dell'Accademia Gioenia di Scienze Naturali, 36 (363): 5-22.

Lillo F., 2008. Specie alloctone: Testuggine palustre dalle orecchie rosse Trachemys scripta (Schoepf, 1792) (Ordine Testudines, Famiglia Emydidae). In: AA.VV., Atlante della Biodiversità della Sicilia: Vertebrati terrestri. Studi e Ricerche, 6, ARPA Sicilia, Palermo, pp. 341-342.

Lillo F., Faraone F.P. \& Lo Valvo M., 2013. Is the painted frog Discoglossus pictus a declining species in Italy? On the reliability of a distributional atlas approach. Amphibia-Reptilia, 34: 248-254.

Liuzzo M., Termine R. \& Marrone F., 2020. First evidence of an egg-laying attempt of feral Trachemys scripta (Schoepff, 1792) in Sicily (Lake Pergusa, Italy). Herpetology Notes, 13: 365-368.

Lo Valvo M., Faraone F.P., Giacalone G. \& Lillo F., 2017. Fauna di Sicilia. Anfibi. Monografie Naturalistiche, 5. Edizioni Danaus, Palermo, 136 pp.

Restivo S., Giacobbe D. \& Lo Paro G., 2010a. Nuovi rilevamenti sull'erpetofauna dell'area peloritana (Sicilia nord-orientale). Atti della Società italiana di Scienze naturali, 151: 77-87.

Restivo S., Giacobbe D. \& Spadola F., 2010b. Rilevamenti erpetologici all'interno della perimetrazione proposta per il Parco Regionale dei Monti Peloritani (Sicilia nord-orientale). Atti VIII Congresso Nazionale Societas Herpetologica Italica: 153: 157.

Sarà M., Massa B. \& Di Vittorio M., 2011. La ricchezza specifica dei Vertebrati in Sicilia. Biogeographia, 30: 637-650.

Sicilia A., 2008. Rospo smeraldino siciliano, Bufo siculus Stöck, Sicilia, Belfiore, Buckley, Lo Brutto, Lo Valvo \& Arculeo. In: AA.VV., Atlante della Biodiversità della Sicilia: Vertebrati terrestri. Studi e Ricerche, 6, ARPA Sicilia, Palermo, pp. 271-272.

Speybroeck J., Beukema W., Dufresnes C., Fritz U., Jablonski D., Lymberakis P., Martínez-Solano I., Razzetti E., Vamberger M., Vences M., Vörös J., Crochet P.-A., 2020. Species list of the European herpetofauna - 2020 update by the Taxonomic Committee of the Societas Europaea Herpetologica. Amphibia-Reptilia, 41: 139-189.

Stöck M., Sicilia A., Belfiore N.M., Buckley D., Lo Brutto S., Lo Valvo M. \& Arculeo M., 2008. PostMessinian evolutionary relationships across the Sicilian channel: Mitochondrial and nuclear markers link a new green toad from Sicily to African relatives. BMC Evolutionary Biology, 8: 56-75.
Stöck M., Grifoni G., Armor N., Scheidt U., Sicilia A. \& Novarini N., 2015. On the origin of the recent herpetofauna of Sicily: Comparative phylogeography using homologous mitochondrial and nuclear genes. Zoologischer Anzeiger, 261: 70-81.

Termine R., 2006a. La Riserva Naturale Speciale del lago di Pergusa. I luoghi, il percorso didattico, la flora, la fauna, le schede, il regolamento d'uso, gli elenchi floro-faunistici. Città Aperta Edizioni, Troina (Enna).

Termine R., 2006b. Programma di lotta biologica-integrata alle zanzare nella conca pergusina, Sicilia. Biologi Italiani, 36: 78-84.

Termine R., Canale E.D., Ientile R., Cuti N., Di Grande C.S. \& Massa B., 2008. Vertebrati della Riserva Naturale Speciale e Sito d'Importanza Comunitaria Lago di Pergusa. Il Naturalista siciliano, 32: 105-186.

Termine R., 2014. Nidificazione di Pollo Sultano Porphyrio porphyrio (Linnaeus, 1758) nella Riserva Naturale Speciale di Pergusa, Enna. In: Tinarelli R., Andreotti A., Baccetti N., Melega L., Roscelli F., Serra L. \& Zenatello M. (a cura di), Atti XVI Convegno Italiano di Ornitologia. Cervia (RA), 22-25 settembre 2011. Scritti, Studi e Ricerche di Storia Naturale della Repubblica di San Marino, pp. 618-619.

Termine R., 2015. R.N.S. Lago di Pergusa. Programma di ricerca sulle componenti ambientali (abiotiche e biotiche) attraverso elaborazioni scientifiche, monitoraggio e rilevazioni parametriche della stazione meteorologica computerizzata. Report 2013-2015. Università degli Studi di Enna "Kore" - Libero Consorzio Comunale di Enna (unpublished).

Termine R., Turrisi G.F., 2016. Sicilian endemic Amphibians and Reptiles of the Nature Reserve of Pergusa Lake (Enna, Italy). In: $1^{\circ}$ Congresso Nazionale congiunto SITE-UZI-SIB, Biodiversity: concepts, new tools and future challenges, Milan 30.0802.09.2016.

Turrisi G.F., 2004. Gli Anfibi e i Rettili della Riserva Naturale Speciale "Lago di Pergusa" (Enna, Sicilia). Università degli Studi di Catania, Relazione Tecnica (unpublished).

Turrisi G.F., 2008a. Discoglosso dipinto, Discoglossus pictus pictus Otth, 1837. In AA.VV., Atlante della Biodiversità della Sicilia: Vertebrati terrestri. Studi e Ricerche, 6, ARPA Sicilia, Palermo, pp. 267-268.

Turrisi G.F., 2008b. Testuggine palustre siciliana, Emys trinacris Fritz, Fattizzo, Guicking, Tripepi, Pennisi, Lenk, Joger, Wink, 2005. In: AA.VV., Atlante della Biodiversità della Sicilia: Vertebrati terrestri. Studi e Ricerche, 6, ARPA Sicilia, Palermo, pp. 277-280.

Turrisi G.F., Lo Cascio P. \& Vaccaro A., 2008. Anfibi e Rettili. In: AA.VV., Atlante della Biodiversità dei Vertebrati terrestri della Sicilia. ARPA Sicilia, Assessorato Territorio e Ambiente, Palermo, pp. 249-372. Turrisi G.F. \& Vaccaro A., 1998. Contributo alla 
conoscenza degli Anfibi e dei Rettili di Sicilia, Bollettino dell'Accademia Gioenia di Scienze Naturali, Catania, 30 (353) (1997): 5-88.

Turrisi G.F. \& Vaccaro A., 2004a. Anfibi e Rettili del Monte Etna (Sicilia orientale). Bollettino dell'Accademia Gioenia Scienze Naturali, Catania, 36 (363) (2003): 5-103.

Turrisi G.F. \& Vaccaro A., 2004b. Status and conservation of herpetofauna from the Iblean area. Atti del $4^{\circ}$ Congresso Nazionale di Erpetologia, giugno 2002 (Societas Herpetologica Italica). The Italian Journal of Zoology, suppl. 2: 185-189.

Vaccaro A. \& Turrisi G.F., 2010. Note sull'erpetofauna di Vendicari (Sicilia sud-orientale). Atti del Convegno "L'area protetta di Vendicari", 25-26 ottobre 2008: 277-286.

Zangari F., Cimmaruta R. \& Nascetti G., 2006. Genetic relationships of the western Mediterranean painted frogs based on allozymes and mitochondrial markers: evolutionary and taxonomic inferences (Amphibia, Anura, Discoglossidae). Biological Journal of the Linnean Society, 87: 515-536. 